\title{
Creating the Writer of the Cleric's Words
}

\author{
CHRISTINA LUPTON
}

\begin{abstract}
This essay argues that, although Anglican sermons were recognised as derivative compositions, it was important to their readers that they were handwritten documents. The discussion traces the effect of handwriting as a virtual dimension of printed writings by and about the clergy, focusing on Tristram Shandy, Mansfield Park and the faux manuscript sermons of John Trusler as texts drawing attention to religious writing at the surface of the page. The article supplements the account given by literary historians of original authorship and creativity as the immaterial categories used to counteract the proliferation of writing in the age of print.
\end{abstract}

Keywords: sermons, remediation, handwriting, Tristram Shandy, Mansfield Park, John Trusler

The sermons compiled in I790 by the maverick publisher the Revd John Trusler appeared on crinkly blue paper, a little like old-fashioned airmail in a script the author himself had designed to look like handwriting. ${ }^{\mathrm{I}}$ Trusler had not really composed the sermons, but had 'culled the flowers' of the best writers of divinity, reissuing well-known texts in this aesthetically pleasing and practical rearrangement for the benefit of working clergymen. His advertisement to them offers 'a specimen of the engraving [... to] be sent to any clergyman, writing for it by the post (post-paid), it being printed on one sheet of paper for the purpose'. The advertisement continues:

Dr. Trusler begs leave to observe, that only 400 copies of any one sermon, are, at any time vended; that they do not pass through the hands of the booksellers, of course, the clergy may rest satisfied that they can never be too general and if they apply to him, will never interfere, and that, as his collection is selected and compiled by the best authors who wrote for fame, he has culled the flowers of the whole, so that, altogether, it is the finest body of Divinity extant, and the engraving is so large as to be read by any eye. One hundred and fifty sermons are on sale now. Gentlemen may have any quantity at Is each, or gd if they take a IOO. $^{2}$

As objects, these sermons embody several paradoxes: they are manuscript-like pages available in the rare books room of the British Library; they are evidence of the newest eighteenth-century technology of print being used to 
reproduce the effect of handwriting; and they appeal in the spirit of literary entrepreneurism to the Anglican clergy's apathy towards new creations. At first view, Trusler's enterprise also seems a literary scandal, one to which Cowper alerts readers when he writes of Trusler in The Task:

\author{
He grinds divinity of other days \\ Down into modern use; transforms old print \\ To zig-zag manuscript, and cheats the eyes \\ Of gall'ry critics by a thousand arts. ${ }^{3}$
}

It is not, however, that these sermons pretend that their recycled content is new. Like so many of the sermons preached in the eighteenth century, these contained fragments and sentiments recognisable as extracts of authorised sermons. The trick is that they appear handwritten - that they appear literally to have had a writer - when the reproductive powers of print meant that they did not. But what did clergymen gain by presenting themselves as the producers of their own derivative but carefully handwritten pages?

My answer to this question structures this argument, which is about penmanship as something that becomes a guarantee of meaning and of labour, drawing public attention to the surface of the page at a time when the focus in literary culture generally is on voice and thought rather than on the authenticity of the page. Creativity features here as something exercised in the presentation of the handwritten, but also as something downplayed in the sphere of concern over the production of Anglican texts. The route my argument will take can thus be described partly as an engagement with accounts of the eighteenth century that suggest the diminishing visibility of writing in the period, in favour of categories such as 'the author' and 'literature'. One version of this argument can be found in Clifford Siskin's The Work of Writing: Literature and Social Change in Britain, I700-I830 (I997), a study justly celebrated for its role in reversing the way we think about the categories by which texts are organised. First, Siskin argues, there was a great proliferation of writing itself - understood here as a nexus of writing, print and silent reading. This abundance of text, its exponential growth evidenced largely in the arena of writing about writing, was resolved by the introduction of the categories in which we now understand texts to originate: disciplinarity, professionalism and literature. Key effects of this organisation were that knowledge was empowered in particular ways. Professionalism emerged as the alternative to literary writing, and literature as an alternative to other kinds of work. The categories enlisted to handle writing therefore emphasise individual labour and character over the constitutive power of writing itself: 'The tendency not to engage writing as a productive, material practice arose', argues Siskin, 'from the very set of social relations to which, in the eighteenth century, writing became indispensably related: the organization of work into mental versus physical labour.'

These terms resonate with other accounts of eighteenth-century literary culture that suggest how ways of thinking about writing at the level of 
content, quality and authorship presented an alternative to its presence earlier in the century as form and quantity. They support, for instance, an account such as Paula McDowell's, which emphasises the production and dissemination of all kinds of literature in the Restoration and the early eighteenth century as physical documents, but then also suggests that this kind of inclusive materiality gave way later in the century to more exclusive, less material, models of authorship. ${ }^{5}$ Cases such as that of Trusler's sermons, however, nuance this story of writing's fading in its materiality in favour of the author, or the meaning of the text, by showing how an increased visibility of the written word also helped various publics deal with the anxieties produced by the proliferation of print.

Trusler's sermon enterprise can also be seen as a case where the medium of print is put to work in substituting handwriting for other kinds of authorial accountability or creativity. 'Remediation', a term coined by Jay David Bolter and Richard Grusin, describes the way in which one medium is represented by another, thus becoming visible at the level of content - or, as Marshall McLuhan argues, as a form of art-while contributing to the invisibility of the media environment that frames it. ${ }^{6}$ Twentieth-century examples of this process involve the way older technologies of film and print take-up and represent technologies of PowerPoint or SMS messaging, and the way in which digital books and web pages use illusions of paper and print in their graphics: envelope icons become signs for e-mail and typewriter font and index cards are digitally reconstructed. In the eighteenth century remediation involved traffic between technologies of voice, handwriting and print in its various forms and results - as woodblock, typeface, handbills, books etc. Handwriting, I will suggest, became visible in new ways at the point where it showed up in these printed texts as content: just when most written materials, including sermons, were being made available through print, experiments such as Trusler's, in styling print to look like long-hand, became popular. This makes his sermons continuous with the occasions within eighteenth-century fiction where print is used to conjure up virtually the image of handwriting as an alternative to the anonymity and proliferation of print. At such points one inscription technology becomes visible as another becomes less so; and handwriting, more specifically, becomes a signifier of labour and commitment at exactly the point where it ceases to be laborious in directly practical terms.

\section{I.}

The best-known case of a sermon appearing in eighteenth-century literature is from Tristram Shandy, where Yorick loses his sermon and has it surface as part of the novel in which he is a character. This involves Sterne giving a full account of the way Yorick's sermon, 'The Abuses of Conscience', makes it into print. In the fictional version of events Yorick has slipped his handwritten sermon between the pages of a borrowed book and then returned the book 
absent-mindedly to its owner, Tristram's uncle Toby. The sermon is discovered by Toby, Walter and Dr Slop, who, puzzled as to the identity of the sermon but deeming it written in a 'fair hand' and unlikely to be published, encourage the servant Trim to read it aloud. ${ }^{7}$ Yorick appears afterwards to claim the sermon and places it in the pocket of his coat. But from here it falls through a hole in the lining of his pocket and is trodden into the mud before being 'raised up out of it by a beggar, sold for a halfpenny to a parish-clerk,-transferred to his parson,- lost for ever to thy own, the remainder of his days' ${ }^{8}$ Soon afterwards the parson who has bought it delivers it:

Can the reader believe, that this sermon of Yorick's was preach'd at an assize, in the cathedral of York, before a thousand witnesses, ready to give an oath of it, by a certain prebendary of that church, and actually printed by him when he had done, - and within so short a space as two years and three months after Yorick's death. ${ }^{9}$

This fictional story of Yorick's sermon intersects, of course, with the real history of Sterne's own sermon of the same name, which he had almost indisputably composed with a sermon of Swift's in mind, then preached at an assize, printed as a sixpenny pamphlet and republished nine years later in the first volumes of his bawdy novel Tristram Shandy.

The ambulatory character of the sermon Sterne describes moving vertiginously between the categories of literature, paper curiosity and pious advice reveals a lot about the real production and circulation of sermons at this point in the eighteenth century. Although I am focusing here on reasons why handwritten sermons show up in printed texts rather than on the actual history of sermon-writing, it is important to keep the key elements of this other history in mind as the basis for public anxiety about the origins of the words they heard in church and read in pious texts. It matters, for instance, that Anglican sermons were defined in opposition to those freely spoken sermons of the Methodists and were formally understood as written compositions, with strict rules for their format and design. This meant that, even when they were composed by an original and pious writer such as Samuel Johnson, they tended to be more imitative or collaborative than works we now think of as original. Martha Woodmansee uses Johnson's habit of ghost-writing and co-writing sermons to illustrate how widely the eighteenth-century reality of composition could deviate from the authorial norm. ${ }^{\text {IO }}$

The fact that Anglican sermons were texts that closely followed a script meant that they were widely perceived even in orthodox circles as written material to be imitated, stylistically and thematically, as well as to be straightforwardly borrowed by members of the clergy. ${ }^{\text {II }}$ In Spectator $106 \mathrm{Mr}$ Spectator recommends country clergy reading an authorised sermon rather than preaching one of their own and describes Sir Roger giving the parson in his service 'a Present of all the good Sermons which have been printed in English' and advising him to read these from the pulpit. ${ }^{\mathrm{I2}}$ This point may seem a little out of date by the time it is made one hundred years later in Mansfield 
Park (I8I4) by Mary Crawford, who suggests to Edmund Bertram that any preacher of good sense will 'prefer Blair's [sermons] to his own' ${ }^{13}$ But the possibility of a man of Edmund's background and integrity using existing material in his composition still resonates in a minor key, increasingly inaudible to later audiences, with a perfectly orthodox line of eighteenthcentury advice to men in his position - literate but not explicitly trained in theology, serious about pastoral care and comfortable with the Anglican canon - against original composition. The fervently religious Jonas Hanway, writing only a few years before Austen, takes a direct stand against the lower clerical orders writing for themselves: 'The peasant may say why should I not write my own poetry, as well as the curate his own sermon?', he muses, but 'both of us might be much better supplied by other people'. ${ }^{\text {I4 Likewise, a }}$ handbook of I 753 advises young clergyman "not to trust at first to their own compositions, but to furnish themselves with a provision of the best sermons, which learned divines of our church have published'. ${ }^{15}$ In 1788 William Temple admits that he 'does not look upon borrowing a good sermon sometimes of Barrow or Jeremy Taylor as a Theft'. ${ }^{\text {I6 }}$

Other manuals advised young clerics to take a craftsman-like approach to sermon-writing, making it a cut-and-paste procedure rather than one of straightforward 'borrowing'. Anthony Moore, vicar of Stratton, advises such pupils to:

Read the best Authors Works, and those alone,

'Till by Degrees you make their Rules your own;

Nor think it means sometimes to steal a Grace,

Or imitate in proper Time and Place;

All have not Parts on Eagle-wing to soar,

And trace out Paths that ne'er were trod before;

Content, with Patience to your Lot submit,

And study to improve what they have writ. ${ }^{17}$

James Woodforde, a perfectly respectable Norfolk parson and diarist who takes on his clerical duty with a dull earnestness, has this compromise in mind when he describes himself 'making' rather than writing the sermons he delivers in neighbouring parishes. He records himself getting up in I764 at two o'clock in the morning 'to get or make a sermon for Farmer Bertelet's funeral this afternoon' and finishing it by noon. ${ }^{18}$ His methods resemble those used by Sterne, whose sermons have been combed by scholars for evidence for and against their originality and are satirised in his characterisation of Yorick, who writes a note on one of his sermons admitting to having stolen the greatest part of it. ${ }^{19}$

These were the prevailing conditions of Anglican sermon-writing in the eighteenth century. But other forces outside the church enabled the ongoing popularity of sermons as reading material. For a start, sermons, like other kinds of texts, were now considered fair game in the world of publishing. Since the English Revolution, argues Rigby, the English sermon had been 
redefined as a printed commodity 'that was losing much of its generic distinction and which was being consumed and interpreted in a richly autonomous market'. ${ }^{20}$ Literary critics still routinely ignore the fact that religious and politico-religious literature remained by far the most commonly produced and widely consumed reading matter throughout the eighteenth century. None of the other forms of reading available by the I750s, including the novel, overtook in sheer quantity the work published in the field of religion. In The Critical Review, for instance, reviews of sermons routinely appear before reviews of novels, suggesting the relative importance and popularity of the genre. ${ }^{2 \mathrm{I}}$ This meant that sermons were often handled by publishers and written by authors in touch with a market and motivated by the professional possibilities of writing. It is the compatibility of the expanding market in print with an existent form of composition and reading, not an expanding interest in Anglicanism per se, that explains the way sermons remained the staple of many livings made in the eighteenth-century book trade, even after their popularity as reading matter was in decline. To this we can add that sermons had a secure customer in the form of the Anglican clergyman who was disinclined, or unable, to write sermons himself and was willing to buy them 'ready made' from men like Trusler or commission them for his own purposes.

Thus in Goldsmith's Citizen of the World an author boasts: 'I have actually written last week sixteen prayers, twelve bawdy jests, and three sermons, all at the rate of sixpence a-piece. ${ }^{22}$ Evan Lloyd's 'Powers of the Pen' (I 766), a verse satire targeting various kinds of writing as mechanically inspired by the pens that write them, describes the lowest kind of work going to 'scripture merchants'. After praising the pens that have served Shakespeare, Sterne and Voltaire, Lloyd describes sermons and divine tracts being pumped from a group of 'dunces' by a writing taskmaster:

Altho' your brains are Lead,

These Quills, my Lads, will get you bread;

Scripture's your Point - build on that Base,

And eat the Bread of Paraphrase -

Perplex, read wrong, and then read right,

Make dark, or you cannot make light:

Let Poets wear the Crown of Bays,

A Belly-full surpasseth Praise. -

The Miracle of Loaves shall You

Exhibit to the World anew;

And of the Bible 'twill be said,

Each Chapter is a Loaf of Bread. ${ }^{23}$

This makes the formulaic nature of sermons seem key to their mass production by the most mechanical of hacks. But Sterne also ghost-wrote at least one sermon and openly saw his sermons as commodities: 'I am taxing the publick', he writes to David Garrick, 'with two more volumes of sermons, 
which will more than double the gains of Shandy.'24 And Johnson boasted to Charles Lawrence that 'the composition of a sermon is not very difficult; the divisions not only help the memory of the hearer, but direct the judgment of the writer' - a boast he backed up by composing, over the course of his career, over forty sermons, for which 'sundrey benificed clergymen' paid him 2 guineas apiece. ${ }^{25}$

Sermons also regularly appeared side by side with other forms of reading material, for instance when they were bound by their owners into new constellations, but also by their printers and publishers. Funeral sermons, especially, are appended to life histories, and sermons in general are popular in anthologies. ${ }^{26}$ The novel also served as a container for presenting all kinds of writing under the cover of a newly pleasurable form, as a space in which pious and didactic writing metamorphoses in a new context, rather than being written differently. As pieces of writing, sermons routinely slip from one reading context to another: this happens, to name only the most famous examples, in Joseph Andrews, in the Vicar of Wakefield and in Tristram Shandy. Fragments of sermons turn up in spaces where it is no longer clear what they are: satire, or instruction, or, even in the case of the notorious example from A Sentimental Journey, erotic double-speak. No wonder, then, that in one satire from I 762 the author imagines himself entering a busy bookseller's to find that the sermons of Baxter, Flavel, Owen and Tillotson have transformed into rather than being displaced by - the novels of Fielding and Richardson. ${ }^{27}$

This traffic between the emerging categories of pleasurable reading and older ones of religious instruction happened partly because some of the new generation of men who wrote sermons in the later part of the eighteenth century saw themselves as writers first and clerics second. For those who left university with ill-defined ambitions and few commitments beyond their literacy, a clerical career was an obvious option. As spaces of relative financial security, they allowed other literary ambitions to be pursued. A man like Sterne, well known as a quirky philanderer, could hold a church living, write sermons that Hunter describes as works of 'arresting mediocrity' and become a declared author of good fiction. He wasn't alone: the Revd James Penn became the author of Surry Cottage (I779), Francis Coventry, curate of Edgware, the author of Pompey the Little (I75I) and the Revd William Cole the author of The Contradiction (I796). And they did so at a time when the clergy in general were seen as dissolute, lazy and increasingly occupied with drinking and gaming, so that adding fiction-writing to this mix did not necessarily help the reputation of the vicar, characterised by Crabbe in I8Io as follows: 'Fiddling and fishing were his arts; at times / He alter'd sermons, and he aim'd at rhymes'. ${ }^{28}$

II.

This convergence of established practices in the Anglican church and new forces in publishing and writing provided eighteenth-century readers with 
ample cause to look closely at the origins of the sermons they encountered, both in church and in print, as documents with a modern secular history, indebted to new cultures of print and to the older customs of the church for their material existence. Trusler, with whose sermons I began, embodies this state of affairs, suggesting through his own practice that it was the need for writing, rather than any religious calling, that led him to become a religious author and literary entrepreneur. It was only after the sale of his first play and an early marriage that Trusler was forced by his father to procure ordination. He accepted a London curacy and became Assistant to the King's Chaplain in I76I. But, by his own account, while fulfilling these roles he struggled to find the leisure to pursue the kind of entrepreneurial writing schemes for which he felt himself better fitted: 'I am convinced', he argued, 'that in making me a clergyman, my father spoilt a good layman.' ${ }^{29}$ When his commercial activities as author and printer eventually took off, Trusler published more than forty of his own works, including books on table manners and gardening, an almanac, editions of prayers with words italicised so as to make it easier to read them aloud, two novels, a book of 'Poetic Endings, or a Dichotomy of Ryhmes, single and double, comprising nearly all the words in the English Language' and the sermons that he sold in limited editions to the clergy. ${ }^{30}$

A career like this justifies the suspicion that many sermons disseminated in England at the time were written primarily for profit. But it also suggests that evidence of their being the true authors of texts was not the only - or, indeed, even the central - thing people wanted from their clerics. Trusler's semiautobiographical novel Modern Times; or, The Adventures of Gabriel Outcast (I785) highlights the fact that a writer who could produce original compositions might easily be seen as a liability to the Anglican church. Born to a family of modest means, Gabriel Outcast is characterised, like Trusler himself, as a boy who likes letters and who finds his way into the church in order to expand his literacy. As a young man, he is employed by a clergyman 'too indolent to write his own sermons' and is set to work copying out stolen ones:

Having purchased a set of manuscripts, which he could not well read, my business was to transcribe them, and now and then to throw in a passage or two which he occasionally penned on a slip of paper, as his leisure moments from hunting, drinking, and the card-table would admit. Indeed, I frequently helped him out, very often adding some passages of my own; so that he would often say I should make a very good parson. ${ }^{3 \mathrm{I}}$

The scandal here is not really that this job description exists. Although the clergyman's relation to sermon-writing is far from ideal, Gabriel's job as secretary could, in a different light, have been represented as one in which he learned reputably from the style of discourse he was to reproduce.

What is more disturbing about the career mapped out in Modern Times is that Gabriel becomes a preacher using the 'stock of sermons' he has acquired 
by working hard as amanuensis in the most material terms: "being furnished with all the requisites of a modern parson, namely, a few sermons, an iron grey suit, and a stock of impudence [...] I applied to Mr. Snuffle, in Paternoster Row, for employ. ${ }^{\prime 2}$ As one of the priests whom Mr Snuffle pimps out at piecemeal rates to parishes and institutions, Gabriel establishes himself as a man of reputation and builds a career as a preacher, at one point travelling to a country parish where he almost succeeds in marrying a rich heiress by introducing himself into the community as a man of high station. Modern Times therefore presents an absolute inversion of a conventional, causal relationship: whereas status, education and piety normally precede the production of good sermons, and where good sermons might therefore operate as the guarantee of these preconditions, in Gabriel Outcast's case the sermons themselves, despite being at least partially his own work, become false guarantees of his character.

In this scenario the congregation's dependence on the category of authorship makes them most vulnerable to Gabriel's mercenary tendencies. At an early point in his career he steals an original sermon for his employer right from the lips of the man who has written it. Gabriel and his master are in Cambridge, where the latter has been enlisted to preach in the morning, and staying next door to them is a clergyman scheduled to preach the next afternoon. As the man next door rehearses his sermon, Gabriel listens through the walls of the room and uses what Downey claims to have been the 'polished art' of shorthand transcription to copy down the words. ${ }^{33}$ The next day, Gabriel's employer reads the stolen sermon aloud in the morning; and when his counterpart delivers the sermon in the afternoon, everyone believes it is he who has copied it: "though he who penned it laboured to have it believed that he was the author of it, it did not avail, the mystery was not unravelled, my master had all the credit, and the afternoon preacher was considered only as a purloiner of the copy. ${ }^{34}$ The duped congregation wrongly dismisses the sincere clergyman (the one who has laboured over his sermon, rehearsing it to himself) in favour of the one they understandably conceive to be its author.

Armed with proof that a congregation will trust anyone who has, or appears to have, written his own words, Gabriel's subsequent career is premised on the understanding that, while one may be caught stealing someone else's words, it is almost impossible to be caught for having a false relation to what one writes. What is needed to protect the public against men like Outcast seems, rather, to be a way of ensuring that individuals identify with the work they do. This defines 'professionalism' in relation to the activity of the individual and the general interests of the professional group, and its performance of a function. 'A profession', writes R. H. Tawney, optimistically opposing it to the threat of capitalist self-interest, "is a body of men who carry on their work in accordance with rules designated to enforce certain standards for the better protection of its members and for the better service of the public.' 35 
Edmund Bertram provides an interesting counterpoint to Outcast in this respect. For while Austen offers no evidence that Edmund will actually write his own sermons, she does provide him with a strong retort to Mary Crawford's doubt that two sermons a week, even from Blair, can 'govern the conduct and fashion the manners of a large congregation for the rest of the week'. Edmund's answer is that the country clergyman's influence is exerted through physical presence and example rather than through sermonising. Austen then upsets this picture by having Edmund, at the end of the novel, take on the living of Thornton Lacey as well as Mansfield Park. But she emphasises his professionalism by making clear his inability simply to perform texts without thought for their meaning, a trait that lines up with Fanny Price's resistance to performance. Both Fanny and Edmund are opposed in Mansfield Park to Henry Crawford, who claims that he can never hear a good sermon 'without the greatest admiration and respect, and more than half a mind to take orders and preach myself' ${ }^{36}$ The argument that both Edmund and his father make about the presence of the clergyman is directly opposed to this theatrical vision of preaching. Edmund's integrity, Austen suggests, will be the crux of his professionalism as well as his rejoinder to a career open to the risk of men like Henry Crawford or Gabriel Outcast performing sermons in which they do not believe.

As someone striving to make physical presence a sign of his commitment to a community, Edmund Bertram also serves to suggest how problematic a component writing is of a clerical life. Once texts are visible, in whatever form, they quickly become evidence of a writer's own interests - at least, of his time having been spent away from the community he serves. Professional writing is in this sense distinguishable from literature because it meets an end and serves the interests of a whole; this means that, the better it is, the less it is writing at all and the more it is an index to a set of behaviours and functions and areas of expertise. As far as professional writing is concerned, argues Siskin, it is not a matter of the technology losing its effectivity, but of the effects being naturalized - that is, relocated into the explanatory matrix of individual, human psychology.' ${ }^{37}$ But when texts make themselves felt through their literary or commercial value, they become distinct from this matrix and a potential threat to the sense of integrity that is settled on the Anglican cleric simply as a man to be believed in his professional capacity.

The fact that Austen does not resolve the question of who will write Edmund's sermons is telling in the sense that it saves her the risk of pinning Edmund's character to his writing, or attributing to him the skills of an author. Rather, Austen creates a limited field of visibility for Edmund's work by insisting most literally on the materiality of his handwriting. She bypasses the question of what he thinks by making him a writer in the most literal sense; a teenager whose caring relationship to his cousin Fanny is established when he stands beside her as she writes her first letter from Mansfield Park, "to assist her with his pen-knife or his orthography, as either was wanted' and who writes on this occasion "with his own hand his love to his cousin 
William', Fanny's brother. ${ }^{38}$ The impression that Edmund makes as a writer deepens later on in the novel, when he leaves an unfinished note to Fanny in her room:

To [Fanny], the hand-writing itself, independent of any such thing it may convey, is a blessedness. Never were such characters cut by any other human being, as Edmund's commonest hand-writing gave! This specimen, written in haste as it was, had not a fault; and there was a felicity in the flow of the first four words, in the arrangement of 'My very dear Fanny,' which she could have looked at for ever. ${ }^{39}$

Although Austen cannot explain how Edmund will manage to be simultaneously present in the company of his parishioners and the author of his own sermons, she resolves this nascent contradiction by making his beautiful writing a literal guarantee of his good intentions. In Fanny's eyes the mediated quality of his unfinished sentence becomes a sign of integrity analogous to that which he promises his parishioners. ${ }^{40}$

Sterne, too, is concerned with handwriting as a key to Yorick's being. Tristram, who is now in possession of his sermons, spends a significant amount of time describing the notes that Yorick has added to his own scripts, acknowledging, as we saw, their degree of originality or commenting on their merit as performances. The notes he uses for doing this include 'moderato' and 'so, so', as well as the self-congratulatory 'Bravo' that Tristram claims sheepishly to have found in one corner of the most sentimental of the sermons.$^{4 \mathrm{I}}$ At this point Tristram homes in on the actual 'writtenness' of the document as redemptive of Yorick's character (and his own, of course) from evidence of vanity: the 'Bravo', he claims, was not written offensively, being 'two inches, at least, and a half's distance from and below the concluding line of the sermon, at the very extremity of the page, and in that right-hand corner of which, you know, is generally covered with your thumb'. And, he goes on:

it is wrote besides with a crow's quill so faintly in a small Italian hand, as scarce to sollicit the eye towards the place, whether your thumb is there or not, - so that from the manner of it, it stands half excused; and being wrote moreover with very pale ink, diluted almost to nothing, - 'tis more like a ritratto of the shadow of vanity, than of VANITY herself. ${ }^{42}$

Then, at the last moment, Tristram claims that the 'Bravo' has, after all, been scored through by his self-deprecating alter ego. Sterne's attention to the pastor's handwriting can be understood as a parody of the kind of attention being paid to script, but it also suggests that the kinds of scrutiny Yorick endures are related to the scanning of writing by the congregation for signs of the writer's intentions.

This brings us back to Trusler's literary venture - the fake manuscript sermons on their blue crinkly paper - and the question with which I began, of 
why good handwriting should have appeared so beneficial to the reputation of the preacher. What aura did the preacher project by reading aloud from beautifully written blue pages sermons that were self-evidently not his own but which he pretended to have written out? How can we explain the fine line that he and his parishioners walked between belief in the 'realness' of the handwriting and the obviousness of its borrowed content? The case of Edmund Bertram underscores the possibility that during the eighty years between Addison recommending that country parsons read aloud from published sermons and the time when Trusler advertised his fake manuscripts for sale, handwriting became one signifier of the clergyman's accountability to his or her audience - not just as the evidence of a professional able to perform his task but as a material sign of his presence in that work. The possibility of handwriting becoming a sign in this way has to do with its appearance of authenticity against the backdrop of print. But if this is the general context for a new appreciation of the clergyman's script, the more particular context has to do with the need for a way of imaginatively binding religious writing to its writers without directly relying on the new and secular categories of authorship and profession. ${ }^{43}$

The product Trusler offered for sale seems to assume that congregation members had their eyes trained on sermons as physical documents, aware of their form as proof of their origin even as they recognised their non-local content. But, as we have seen, this kind of legibility was most powerful virtually, with handwriting like Yorick's and Edmund's represented in print as a remediated source of immediacy and proof of presence. It is through such remediation, for instance, that Sterne could use print to index his own presence at his desk, by invoking the 'handwrittenness', not just of Yorick's sermons, but of his novel as a whole:

And this moment that I last dipp'd my pen into my ink, I could not help taking notice what a cautious air of sad composure and solemnity there appear'd in my manner of doing it. - Lord! how different from the rash jerks, and harebrain'd squirts thou art wont, Tristram! To transact it with in other humours, dropping thy pen, - spurting thy ink about thy table and thy books, - as if thy pen and thy ink, thy books and thy furniture cost thee nothing. ${ }^{44}$

Sterne becomes visible in references such as these as an author gathering readers around his desk as witnesses to his writing process. ${ }^{45}$ And while Tristram also frequently refers to himself as the manager of a printed book, positioning himself as the wielder of pen and ink has distinct advantages. In the case of both Tristram and Yorick the writer's posture functions to account for what their bodies are doing during the various scenes they describe. Tristram Shandy is a text designed to evidence Sterne's own hands, being, as it were, on the table: he can write about the sexual exploits of his characters because his own body remains squarely in view as a writing body. Yorick's writing a preface in an old coach may conjure up images of onanism, but 
finally it is only writing: it works quite literally as a way of keeping the author's hands occupied.

These images of the writer's hand work to reintroduce the body to a process from which it appears severed when print introduces the written without writing. Being reminded of Yorick and Tristram as writers we are encouraged to make a connection between the writing body and printed text that feels immediate but is, of course, literally unimaginable. The move by which Sterne announces the writing process, perpetuating what is often celebrated as his spirit of candour about the material status of his fiction, is therefore a thoroughly virtual one, introducing the hand to a process in which real hands are less visible than ever. In other words, while the very excesses of print make it impossible to locate it in the labour of any one subject, the invention of the author as a category allows this discourse to appear reflexive about its own mediation. In reminding us so literally of the writing process behind his content, Sterne is genuinely referring us to mediation as a fact, but in attracting our attention to this fact at the level of content he is also distracting readers from its appearance as form. Tristram Shandy, in this sense, is rather like the television series (of which there are now several) in which characters are engaged professionally in the business of writing film scripts. While their activities and concerns refer in some general sense to the constitution of the show we are watching as a form of mediation, the human scale of their activity obscures the very real sense in which no hand is involved in the creation of what we see.

I am going to end with the case of William Dodd, the 'macaroni parson' as he became known, who was routinely satirised in the later years of his life..$^{46}$ In the I76os Dodd had become a figure of some note in London: he had built his own chapel and his preaching was attracting fashionable crowds. His sermonising, described by Horace Walpole as being in the 'French' style, was flamboyant and eloquent, and he drew noticeably more attention and money from his congregation than Sterne, who was his direct contemporary and preached in some of the same locations. But Dodd's fortunes went downhill, and after a period as tutor to Lord Chesterfield, he turned, like Trusler, to what one biographer describes as 'Religious Hack-Work'. Despite this, in his critique of Dodd, Cowper portrays him in The Task (I785) as a lazy philanderer, explicitly noting the absence of the pen in his hand:

[...] loose in morals, and in manners vain,

In conversation frivolous, in dress

Extreme, at once rapacious and profuse,

Frequent in park, with lady at his side,

Ambling and prattling scandal as he goes,

But rare at home, and never at his books

Or with his pen, save when he scrawls a card. ${ }^{47}$

This critique promotes reading and writing as activities that would secure Dodd's presence at his desk - and therefore away from the park and from his 
flirtations - without actually specifying what he should write there. And ironically, his handwriting did become something scrutinised as it was remediated by print in the final months of his life.

Dodd's final notoriety came in I777, when he was caught and hanged for having forged a bond in the name of his old student Lord Chesterfield for the sum of $£_{4,200}$. The bond securing this debt had already passed muster, and Dodd was in possession of the money when suspicion was aroused about the authenticity of the document: 'there were some strokes above and below the bond, that had a very singular appearance; one cannot very well tell, but they looked to be done with a pen; there are some scratches as if it was done, or attempted to be done on purpose. ${ }^{48}$ These notes from Dodd's trial are explicit about the fact that what gave Dodd away was a blot suspicious because it suggested that too much attention had been paid to the writing of the bond, with the scratches on the document suggesting this same excess of purpose. Although the blot itself carried no actual meaning, descriptions of it featured in Dodd's trial, where Mr Manly explained, in his own words, that he found it to be 'a blot of a particular and remarkable nature: it did not appear to me to be the effect of chance, but the operation of a pen. The action of a pen in a particular manner; in the hair stroke it is very remarkable.' ${ }^{49}$ The emphasis here is on the anomalous nature of a mark that suggests the suspicious character of its author.

After observing the blot, Manly and Fletcher turned to Chesterfield to verify the bond. But Chesterfield, of course, knew nothing about it, and Dodd was soon charged with, and admitted to, the forgery. The ensuing trial, which attracted a great deal of media attention, focused on the topic of Dodd's handwriting. Witnesses testified to his writing having been widely known in the town, thus correcting in some measure the perception of his idleness but also, no doubt, drawing attention to the scandalous fact that he was on trial as a gentleman, educated in ways that reference to his handwriting would have suggested. Dodd also won public sympathy because during the period of his trial he became a prolific writer of letters, sermons and poems, mounting his defence largely by way of application of pen to paper. Many of the documents published as his writing during this time were not actually his own work. Samuel Johnson took up the pen in his name, writing the sermon that Dodd delivered in prison as well as letters to the king on his and his wife's behalf. Underlying the irony of these forgeries is the sense that Johnson perceived it as being necessary to make Dodd appear again to be a writer, to show him doing penance by penning more lines than he was literally capable of writing.

Although Johnson's efforts were to no avail, with Dodd being hanged to public outcry and a notable lack of protest from Chesterfield, the case demonstrates that the reading public were willing to engage in an imaginative operation by which print was used to conjure up the power of handwriting. The published debates around the trial used print quite directly to testify to the quality of Dodd's handwriting, to reproduce for readers of print the action of 
the pen as something that was at stake in the character of a clergyman. Publicity for the case involved numerous reports in which the bond was closely described so as to be graphically recalled through print. Dodd's prison writings were published, I would suggest, as material evidence of his status and his activity in prison as much as for their plaintive contents. The printed versions of what he wrote may therefore be understood in this sense as a remediation of his handwriting, which was used as evidence both of his character and of this character's undoing. In the general climate of concern about handwriting as something that Dodd had done too little of, and then too much of, writing itself came into view as a palliative activity through which he would restore his public accountability while the print culture that supported this controversy became, at least at this juncture, simply the natural environment for the debate.

As documents that call attention to handwriting, Trusler's sermons, printed and marketed ten years after Dodd's execution, become paradigmatic of a culture in which looking at writing is still an occupation of the modern reader. In contrast to the looking through texts which helped to constitute authorship, literature and professionalism as organising categories, this kind of reading really did involve looking at the surface of the page. But this is in no way to suggest that eighteenth-century readers engaged simply with the materiality of texts and inscription. Rather, eighteenth-century texts that call attention to themselves as products of labour do so in a double-edged process by which they render certain inscription techniques visible as forms of art while allowing others to continue unabated and invisible. Ironically, in order to perceive the written materiality of Dodd's letters from prison as they appeared in the newspaper, of Edmund Bertram's note to Fanny, of Yorick or Trusler's sermons, one must actively forget that the screen on which they appear is that of print. The activity of scrutiny in which the reader is engaged therefore takes one further from the kinds of bodily contact and evidence that handwriting suggests even as it promises to return them. But it is exactly this combination of remembering and forgetting that characterises the forms of textual self-consciousness promoted by Trusler's sermons, in which a text recalls its own scene of production virtually in order to make itself appear more real.

\section{NOTES}

I. John Trusler, Twelve Sermons (London, I796), British Library, shelf no.4905, fol.6. References in Trusler's autobiography and from other critics show that these sermons also existed in earlier editions.

2. A List of Books Published by the Reverend John Trusler At the Literary Press, No. 62, WardourStreet, Soho (London, I790), p.IO.

3. William Cowper, The Task, II.362-5, in The Poems of William Cowper, ed. John D. Baird and Charles Ryskamp, 3 vols (Oxford: Clarendon Press, I980-95), vol. II.I48.

4. Clifford Siskin, The Work of Writing: Literature and Social Change in Britain, I700-I830 (Baltimore, MD: Johns Hopkins University Press, I998), p.I76.

5. Paula McDowell, The Women of Grub Street: Press, Politics, and Gender in the London Literary Marketplace, I678-I730 (Oxford: Clarendon Press, I998). 
6. For the most recent articulation of this concept, see Jay David Bolter and Richard Grusin, Remediation: Understanding New Media (Boston, MA: MIT Press, 2000). For Marshall McLuhan's earlier description of the processs of making mediation art, see 'The Invisible Environment: The Future of an Erosion', Perspectiva II (I967).

7. Laurence Sterne, The Life and Opinions of Tristram Shandy, Gentleman, ed. Melvyn New and Joan New, 3 vols (Gainsville, FL: University Press of Florida, I978-84), vol. I.I38 (Vol. 2, Chapter I5).

8. Sterne, Tristram Shandy, vol. I.I66 (Vol. 2, Chapter I7).

9. Sterne, Tristram Shandy, vol. I.I67 (Vol. 2, Chapter I7).

Io. Martha Woodmansee, 'The Author Effect', in Martha Woodmansee and Peter Jaszi (eds), The Construction of Authorship: Textual Appropriation in Law and Literature (Durham, NC: Duke University Press, I994), p.2I.

II. Paul Hunter describes sermons like this: 'Behind them are recognizable conventions and habits of mind, and in them is careful if undistinguished writing': Before Novels: The Cultural Contexts of Eighteenth-Century English Fiction (New York: W. W. Norton, I992), p.249.

I2. Joseph Addison, Spectator I06 (2 July I7II), in Donald F. Bond (ed.), The Spectator, 5 vols (Oxford: Clarendon Press, I965), vol. I.44I.

I3. Jane Austen, Mansfield Park, ed. James Kinsley, with intro. and notes by Jane Stabler (Oxford: Oxford University Press, 2003), p.73.

I4. Jonas Hanway, A Journal of Eight Days Journey from Portsmouth to Kingston upon Thames (London, I756), p.53.

I5. Quoted in Lansing V. Hammond, Laurence Sterne's Sermons of Mr. Yorick (New Haven, CT:

Yale University Press, 1948), p.66.

I6. Quoted in James Gray, Johnson's Sermons: A Study (Oxford: Clarendon Press), p.I7.

I7. Anthony Moore, An Essay on the Art of Preaching, Addressed to the Clergy (London, I758), p.27.

I8. John Beresford (ed.), The Diary of A Country Parson: The Reverend James Woodforde, 5 vols (London: Oxford University Press, I924-3I), vol. I.36.

I9. For a recent discussion of Sterne's sermons, their origins and their fate as commodities, see Tim Parnell, 'The Sermons of Mr. Yorick: The Commonplace and the Rhetoric of the Heart', in Thomas Keymer (ed.), The Cambridge Companion to Laurence Sterne (Cambridge: Cambridge University Press, 2009), p.50-64.

20. James Rigby, "'To lye upon a Stationer's Stall, like a Piece of Coarse Flesh in a Shambles": The Sermon, Print and the English Civil War', in Lori Anne Ferrell and Peter McCullough (eds), The English Sermon Revised: Religion, Literature and History, I600-I750 (Manchester: Manchester University Press, 2000), p.I92.

2I. Hunter offers an extended discussion about the contexts in which sermons are published: Before Novels, p.245-50.

22. Oliver Goldsmith, The Citizen of the World; or, Letters from a Chinese Philosopher, Residing in London, to his Friends in the East, 2 vols (London, I762), vol. I.I22.

23. Evan Lloyd, The Powers of the Pen. A Poem addressed to John Curre, Esqr (London, Richardson and Urquhart, I766), p.33-4

24. Letter to Garrick, I6 March I 763, in Lewis Perry Curtis (ed.), The Letters of Laurence Sterne (Oxford: Clarendon Press, I935).

25. See Gray, Johnson's Sermons, p.8, 9. Gray (p.I7) describes clergymen writing 'request sermons' for each other, rather in the way that essays are ordered today by students to meet the demands of a particular assignment.

26. See Hunter, Before Novels, p.250.

27. Jack and his Whistle. With Annotations. To which is added, A Paper dropt from Tristram Shandy's Pocket-book (Edinburgh, I762), p.3.

28. George Crabbe, The Borough, Letter III, l.IO2-3, in The Borough: A Poem, in Twenty-Four Letters (Philadelphia, PA: Bradford and Inskeep, I8Io), p.32.

29. Memoirs of the Life of the Rev. Dr. Trusler, written by himself (Bath: John Browne, I806), part I, p.79-80.

30. These are all listed in Trusler, A List of Books Published.

3I. Trusler, Modern Times; or, The Adventures of Gabriel Outcast. Supposed to be Written by Himself, 3 vols (London: Printed for the Author, by the Literary Society, I785), vol. I.I29.

32. Trusler, Modern Times, vol. I.I36-7.

33. James Downey, The Eighteenth-Century Pulpit (Oxford: Clarendon Press, I969, p.5. 
34. Trusler, Modern Times, vol. I.I3I-2.

35. Quoted in Thomas L. Haskell, 'Professionalism versus Capitalism: R. H. Tawney, Emile Durkheim, and C. S. Peirce on the Disinterestedness of Professional Communities', in Thomas Haskell (ed.), The Authority of Experts: Studies in History and Theory (Bloomington, IN: Indiana University Press, I984), p.I80.

36. Austen, Mansfield Park, p.I7I.

37. Siskin, The Work of Writing, p.24.

38. Austen, Mansfield Park, p.I3.

39. Austen, Mansfield Park, p.208.

40. Fanny's response to Edmund's handwriting also suggests the social significance of handwriting in the eighteenth century, which conveyed a great deal more information about the socially constructed self - its station, class, gender and profession - than it does today, despite the fact that it was not seen as a direct expression of the individual. What Fanny reads in Edmund's hand, and what Austen's readers visualise at the point it is described, is a very particular kind of handwriting: proficient, commanding, natural, controlled and, above all, distinguishable in its very nature as a reminder of Edmund's station in life. See, for instance, Tamara Plakins Thornton, Handwriting in America: A Cultural History (New Haven, CT: Yale University Press, I996).

4I. Sterne, Tristram Shandy, vol. II.5I5-I6 (Vol. 6, Chapter II).

42. Sterne, Tristram Shandy, vol. II.5I6 (Vol. 6, Chapter II).

43. In The Task, Cowper invokes the literal act of writing as a metaphor for the kind of presence a pastor will have: 'Would I describe a preacher, such as Paul / Were he on earth, would hear, approve, and own, / Paul should himself direct me. I would trace / His master-strokes, and draw from his design' (II.395-8).

44. Sterne, Tristram Shandy, vol. I.254 (Vol. 3, Chapter 29).

45. Hunter, Before Novels, p.238.

46. This is evidenced in Samuel Foote's play The Cozeners ( $\mathrm{I} 778$ ), where Dodd is represented as Dr Simony.

47. Cowper, The Task, II.378-84.

48. A Full and Circumstantial Account of the Trial of the Rev. Doctor Dodd (London: Richardson and Urquhart, I777), p.IO.

49. A Full and Circumstantial Account, p.I6-I7.

CHRISTINA LUPTON is Assistant Professor of English at the University of Michigan. Her work is focused on the way literary works draw attention to their own materiality. She has recently completed a manuscript on 'Knowing Books: The Consciousness of Mediation in EighteenthCentury Britain' and has published on Sterne, Hume, Goethe, Franklin, Fielding and it-narratives. 